\title{
Acropora distribution patterns in the northern and northeastern Persian Gulf
}

\author{
Mohammad Reza Rahmani ${ }^{1,2,3^{*}}$, Hassan Rahimian ${ }^{1}$, Mahnaz Ardalan² ${ }^{2}$ Shashank Keshavmurthy ${ }^{4}$, Silvia Fontana ${ }^{4,5}$, \\ Carden C Wallace ${ }^{6}$ and Chaolun Allen Chen ${ }^{4,5,7^{*}}$
}

\begin{abstract}
Background: Acropora species distribution patterns at Larak, Farur, and Khark Islands along the Iranian coast were investigated from October 2008 to November 2009 based on a previous study conducted on the taxonomy of Acropora by examining 1,169 colonies.

Results: The analysis showed that the species diversity and evenness were low at the three islands, but the total percentage cover of Acropora was relatively high at Larak (38.52\%) with lower cover at Khark (24.01\%). The Acropora community at Larak Island was significantly dissimilar to those at Farur and Khark Islands, whereas the latter two possessed similar community structures. Chlorophyll a differences of Larak with Farur and Khark Islands coincided with Acropora community differences among these islands.

Conclusions: Relatively high coral coverage found at the islands off the Iranian coast suggests important implications for coral reef resilience and mitigation (e.g., assisted migration) in response to changing environmental conditions, not only for the Persian Gulf but also for the world's coral reefs under the impacts of climate change.
\end{abstract}

Keywords: Coverage; Island; Species composition; Abundance

\section{Background}

The Persian Gulf, an extension of the Indian Ocean located in west Asia between Iran and the Arabian Peninsula, is characterized by extreme environmental conditions, including high salinities, temperature fluctuations, extremely low tides, winter macroalgal blooms, and pollution (reviewed in Coles 2003; Riegl and Purkis 2012). For instance, salinity regularly exceeds $45 \mathrm{ppt}$, and sea surface temperatures (SSTs) annually fluctuate from summer highs of $>36^{\circ} \mathrm{C}$ to winter lows of $<12^{\circ} \mathrm{C}$ in the southern and western Persian Gulf (Coles and Fadlallah 1991; Sheppard et al. 1992). These environmental conditions reduce the number of reef-building corals to species that can tolerate these extremes and result in the occurrence of only about $10 \%$ of the species that inhabit the Indo-Pacific region (Coles 2003; Riegl et al. 2012). Thus, gulf coral assemblages differ from typical reef communities that exist in tropical and

\footnotetext{
*Correspondence: rahmani@coe.ac.ir; cac@gate.sinica.edu.tw

${ }^{1}$ Faculty of Biology, College of Science, University of Tehran, Tehran 14155-6453, Iran

${ }^{4}$ Biodiversity Research Center, Academia Sinica, Nangang, Taipei 115, Taiwan Full list of author information is available at the end of the article
}

subtropical reefs of the Indian and Pacific Oceans (Coles 2003).

Studies on coral diversity and distributional patterns have generally focused on the southern Persian Gulf (reviewed in Riegl et al. 2012). Compared to Indo-Pacific reefs, coral communities in the southern Persian Gulf show relatively low species diversity with a dominance of species in the families Dendrophyllidae, Siderastreidae, and Faviidae, and a few species in the family Acroporidae (Coles 2003). In the gulf region, relatively higher species diversity (40 species) was found in the central gulf along the coast of Saudi Arabia and Bahrain, with a decrease towards Kuwait (35 species) to the north and United Arab Emirates (34 species) to the south (Coles 2003). Moreover, the number of coral species increases to 49 towards the Strait of Hormuz (Bauman et al. 2013). In contrast to the intensive surveys and monitoring of coral diversity elsewhere in the gulf, studies on the coral fauna of the northern Persian Gulf, i.e., the Iranian coast and its islands, were only carried out in the past decade (Fatemi and Shokri 2001; Rezai et al. 2004, 2007, 2009; Kavousi et al. 2011; Riegl et al. 2012; Rahmani and Rahimian 2013). Preliminary results showed a trend 
of decreasing coral diversity from east to west and from north to south (reviewed in Riegl et al. 2012). Further studies are necessary to comprehensively document coral diversity and distributional patterns along the Iranian coast in order to reveal the full picture on coral diversity in the Persian Gulf.

Following up on previous work conducted on the taxonomy of Acropora species from three islands, Larak, Farur, and Khark, along the Iranian coast (Rahmani and Rahimian 2013), we present a quantitative analysis of Acropora spp. diversity in this paper. In addition, we combined distribution data with prevailing local environmental parameters (SST, photosynthetically active radiation (PAR), colored dissolved organic matter (CDOM), and chlorophyll (Chl) a) to elucidate relationships, if any, between the presence of Acropora spp. and the local environment. In addition, we also appraised geographic patterns of east-west and north-south decreases in coral species diversity using distribution data from the three islands.

\section{Methods}

\section{Permits for coral survey and sampling}

No special permits are required in Iran when sampling for scientific purposes with an approved research proposal from academic or government agencies. Sampling of corals was kept to a minimum (i.e., a maximum of $2 \%$ of a colony) in keeping with regulations. The eastern part of Khark Island that is allocated to loading oil tankers is designated a restricted zone where coral surveys are prohibited.

\section{Study area, field survey, and laboratory examination}

The study area around the three islands, Larak, Farur, and Khark, located in the northern part of the Persian Gulf was described in (Rahmani and Rahimian 2013) (also see Figure 1). The coral reefs of these islands are among the most diverse locally and are limited to the north and northwestern parts of Larak with some being present at Farur and Khark Islands as well. Data used to quantify Acropora diversity in this study were collected

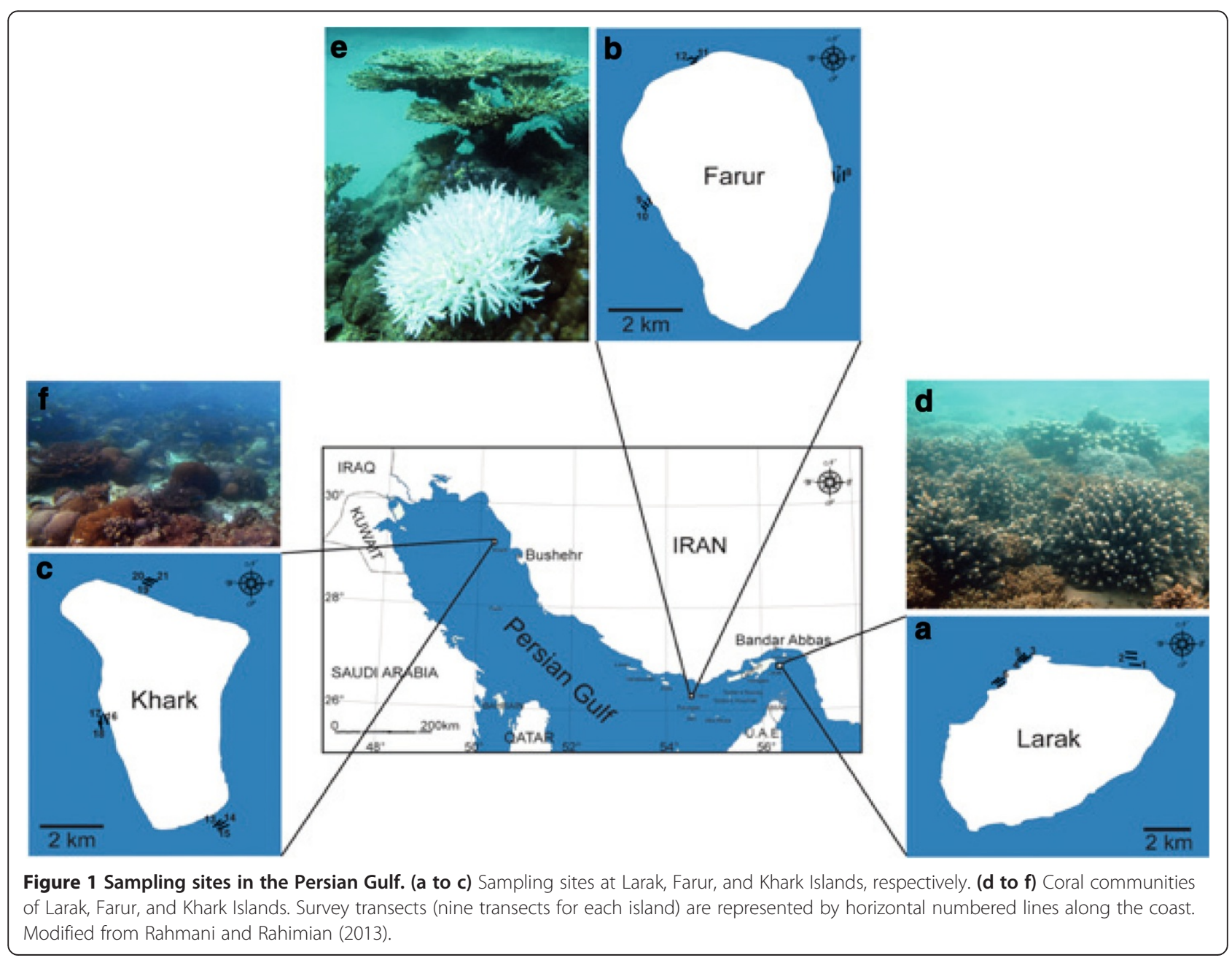


during field surveys in a previous study (Rahmani and Rahimian 2013). Since the Persian Gulf coral distribution is patchy and live coral coverage (LCC) and Acropora spp. colony sizes are diverse, a modified version of the linear point intercept transect (Riegl 1999; Beenaerts and Berghe 2005) was used to survey these parameters. Nine sampling sites (three transects each at three depths at each location) were selected for each island (Figure 1). Twenty-meter transects separated by 5 -m gaps were laid out at each depth transected at each site. Each transect was marked at $50-\mathrm{cm}$ intervals. The starting point for each transect was selected randomly. On each transect, all Acropora colonies regardless of the species were counted, and the diameters of the colonies were measured to the nearest millimeter. Diameters of all Acropora colonies were summed and divided by the total transect length to calculate the coverage. A 160-cell table was prepared, with each cell representing a $0.5-\mathrm{m}$ interval of each transect. The species composition at each interval was recorded in a specific cell that indicated the point of observation along the transect. The species composition and abundance at each transect were used to calculate the species richness $(S)$, evenness, and diversity.

\section{Environmental variables}

Monthly means of SST, PAR, Chl $a$ concentrations, and CDOM (in surface waters) for marine areas adjacent to Larak, Farur, and Khark Islands were acquired from the Giovanni online data system for the period between January 2007 and December 2011. All data were from the MODIS-Aqua 4-km-resolution database. The Giovanni online data system was developed and is maintained by NASA GES DISC (http://gdata1.sci.gsfc. nasa.gov/daac-bin/G3/gui.cgi?instance_id=ocean_month). Data were accessed and downloaded during the period of 10 to 15 November 2012.

\section{Statistical analysis}

Acropora species composition and diversity patterns were compared among locations. An analysis of similarity (ANOSIM) was used to test for differences in Acropora community compositions between locations (Clarke and Warwick 2001) and plotted using multidimensional scaling (MDS) and SIMPER analyses to determine which Acropora species contributed to community differences (Clarke and Warwick 2001). Patterns of coral species diversity among locations were then calculated using three diversity metrics of $S$, Shannon-Weaver diversity index $\left(H^{\prime}\right)$, and Pielou's evenness $\left(J^{\prime}\right)$. These metrics were analyzed using a one-way analysis of variance (ANOVA) and post hoc unequal- $N$ honestly significant difference (HSD) tests. Analyses were conducted using PRIMER (version 5 for Windows; PRIMER-E Ltd., UK).
For environmental variables, a one-way ANOVA was conducted to compare SST, PAR, Chl $a$, and CDOM among sites, and the Bonferroni test (Abdi 2007) was used to examine significant differences (after confirmation through the one-way ANOVA) with environmental data among the three islands. A statistical analysis of environmental variables was carried out using Aabel (build 3.06 for Macintosh; Gigawiz Ltd. Co., USA). Relationships between environmental variables and coral communities were analyzed using BEST and LINKTREE in PRIMER (version 6 for Windows; PRIMER-E Ltd., UK) to find the best match between multivariate amongsample patterns of Acropora communities and from environmental variables associated with those samples.

\section{Results}

\section{Acropora diversity}

Ten Acropora species within the study area were identified in a previous study (Rahmani and Rahimian 2013). Acropora downingi was the most abundant species among them with relative coverage ranging from $29.08 \%$ at $6 \mathrm{~m}$ to $0.47 \%$ at $9 \mathrm{~m}$ at Larak. Acropora arabensis was the second most abundant species with relative coverage ranging from $9.91 \%$ at $3 \mathrm{~m}$ at Larak to $1.62 \%$ at $3 \mathrm{~m}$ at Khark. The other species were sporadically distributed around the three islands. There was a deceasing trend in species numbers from the Strait of Hormuz (seven species at Larak) to the inner part of the Persian Gulf (three species at Khark).

\section{Acropora community}

$S, H^{\prime}, J^{\prime}$, and the total percentage cover (TPC) among the three islands are given in Table 1 . These indices showed low species diversity and low evenness in these islands. $S$ and $H^{\prime}$ values showed significant differences among locations (ANOVA, $F_{(2,22)}=8.19$ and $F_{(2,22)}=6.31$, respectively, $p<0.05)$, but no significant differences were found for evenness or TPC (ANOVA, $F_{(2,22)}=2.11$ and $F_{(2,22)}=0.37$, respectively, $\left.p>0.1\right)$. While a significant difference in $H^{\prime}$ values was detected between Khark and Larak (HSD test, $p<0.006$ ), no significant difference in $H^{\prime}$ values was observed between Farur and the two other islands. None of the metrics showed dissimilarities between surveyed sites and depth at any island. However, the

Table $1 S, H^{\prime}, J^{\prime}$, and TPC from Larak, Farur, and Khark Islands in the northern Persian Gulf

\begin{tabular}{lcccc}
\hline Location & $\begin{array}{c}\text { Richness } \\
(\boldsymbol{S})\end{array}$ & $\begin{array}{c}\text { Diversity } \\
\left(\boldsymbol{H}^{\prime}\right)\end{array}$ & $\begin{array}{c}\text { Evenness } \\
\left(\boldsymbol{J}^{\prime}\right)\end{array}$ & $\begin{array}{c}\text { Total percent } \\
\text { cover (TPC) } \\
(\overline{\boldsymbol{x}} \pm \text { SD })\end{array}$ \\
\hline Larak & $7^{\mathrm{a}}$ & $0.817^{\mathrm{a}}$ & 0.420 & $38.62 \pm 11.75$ \\
Farur & 6 & 0.613 & 0.342 & $29.80 \pm 0.39$ \\
Khark & 4 & 0.416 & 0.300 & $24.01 \pm 2.15$ \\
\hline
\end{tabular}

${ }^{\mathrm{a}}$ Significant difference at $p<0.05$. 
ANOSIM indicated significant differences in species composition among locations (global $R=0.54, p<0.001$ ). Pairwise comparisons (Table 2) and MDS ordination plots (Figure 2) showed significant differences between islands (Larak $\times$ Farur: $R=0.53, p<0.002$; Larak $\times$ Khark: $R=0.70$, $p<0.001$; Farur $\times$ Khark: $R=0.43, p<0.003)$. The SIMPER analysis indicated that Farur and Khark had similar species compositions (23.14\% dissimilarity), whereas Larak had a distinct species composition compared to Farur (31.36\%) and Khark (38.70\%). The Acropora community at Larak was composed of A. downingi, A. arabensis, Acropora valida (3 and $6 \mathrm{~m})$, Acropora muricata (3 m), Acropora horrida (6 m), Acropora mossambica (3 and $6 \mathrm{~m})$, and Acropora nasuta (3 and $6 \mathrm{~m}$ ). While at Farur and Kharak, the Acropora community was mainly composed of $A$. downingi, $A$. arabensis, $A$. valida, A. horrida, and Acopora tortuosa (only at Frur) and Acropora aspera (see Table 3).

\section{Environmental variables}

Average monthly SST, PAR, Chl $a$, and CDOM values among Larak, Farur, and Khark are shown in Figure 3. Analysis of monthly mean SSTs indicated no significant difference in seasonal patterns of temperature fluctuations among the three locations (one-way ANOVA,
$F=0.814118, p=0.452)$ with mean SSTs of $25.69^{\circ} \mathrm{C}$ at Khark, $27.87^{\circ} \mathrm{C}$ at Farur, and $27.59^{\circ} \mathrm{C}$ at Larak (Figure 3). Similarly, PAR values among the three locations did not significantly differ (one-way ANOVA, $F=0.114264$, Bonferroni test, $p>0.5$ ). In contrast, there were significant differences in CDOM values between Khark and Farur (one-way ANOVA, $F=9.41251$, Bonferroni test, $p<0.001$ ), in Chl $a$ values between Larak and Khark (one-way ANOVA, $F=3.81123$, Bonferroni test, $p<0.009$ ), and in Chl $a$ values among the three locations $(p<0.05)$. The LINKTREE analysis (Table 4$)$ of Acropora communities showed only a split dividing sites associated with Chl $a$ and CDOM $(R>0.5, p<0.83$; $n=831$ ). In the BIO-ENV test (Table 5), these factors (Chl $a$ and CDOM) were more effective than other factors (SST, PAR, and transparency).

\section{Discussion}

Acropora fauna in the Persian Gulf is characterized by relatively low species diversity compared to counterparts in the Indo-Pacific region (reviewed in Wallace 1999; Riegl et al. 2012). The latest summary of Acropora species based on intensive studies from the southern and western Persian Gulf and a few preliminary surveys

Table 2 Percentage dissimilarity $(\delta)$ of Acropora identified by SIMPER

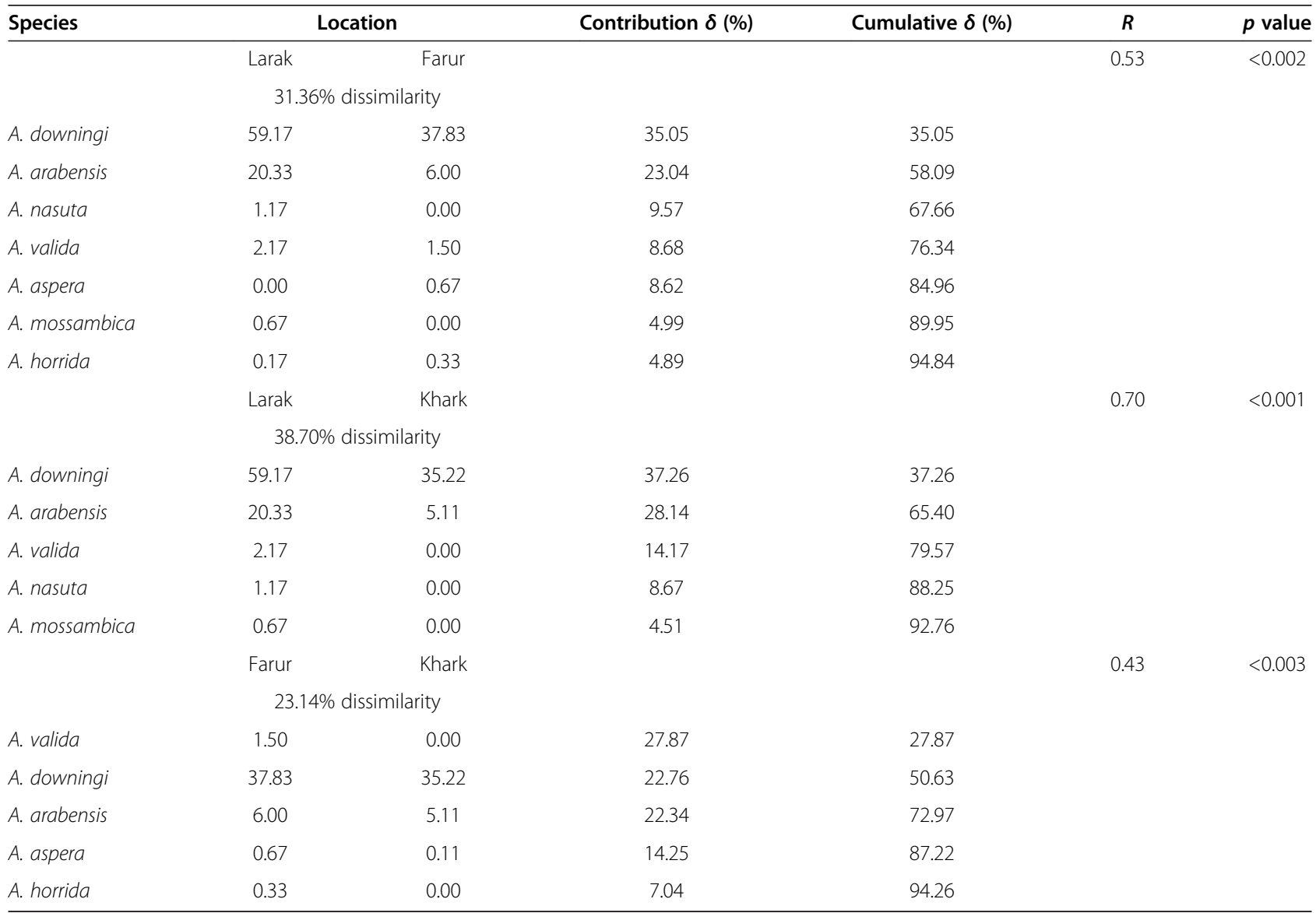




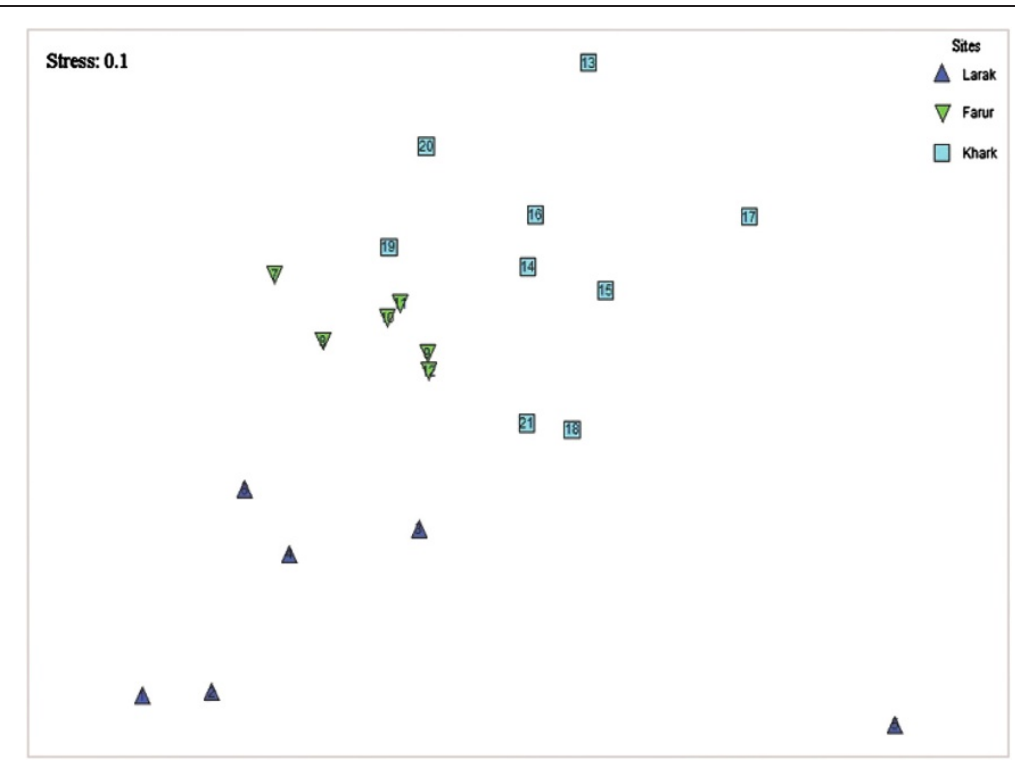

Figure 2 MDS ordination plots of Acropora communities in the northern and northeastern Persian Gulf. Symbol numbers correspond to transect numbers shown in Figure 1. Transects without numbers indicate that no Acropora spp. were found at those survey sites.

Table 3 Relative coverage and numbers of colonies examined (in parenthesis) for Acropora species

\begin{tabular}{|c|c|c|c|c|c|c|c|c|}
\hline \multirow[t]{2}{*}{ Species } & \multicolumn{3}{|c|}{$\begin{array}{c}\text { Larak } \\
\text { Depth (m) }\end{array}$} & \multicolumn{2}{|c|}{$\begin{array}{c}\text { Farur } \\
\text { Depth (m) }\end{array}$} & \multicolumn{3}{|c|}{$\begin{array}{c}\text { Khark } \\
\text { Depth (m) }\end{array}$} \\
\hline & 3 & 6 & 9 & 6 & 9 & 3 & 6 & 9 \\
\hline \multirow[t]{2}{*}{ A. downingi } & $28.41 \pm 3.73$ & $29.08 \pm 9.12$ & $0.47 \pm 0.33$ & $24.92 \pm 1.25$ & $23.57 \pm 1.20$ & $23.88 \pm 5.57$ & $23.13 \pm 15.52$ & $15.81 \pm 4.08$ \\
\hline & (149) & (225) & (2) & (116) & (111) & (118) & (114) & (85) \\
\hline \multirow[t]{2}{*}{ A. arabensis } & $9.91 \pm 3.64$ & $7.76 \pm 0.96$ & $2.34 \pm 1.39$ & $3.44 \pm 0.23$ & $4.25 \pm 0.23$ & $1.71 \pm 1.22$ & $1.62 \pm 0.46$ & $5.58 \pm 1.83$ \\
\hline & (52) & (60) & (10) & (16) & (20) & (8) & (8) & (30) \\
\hline \multirow[t]{2}{*}{ A. valida } & $1.14 \pm 0.40$ & $0.90 \pm 0.42$ & - & $0.86 \pm 0.18$ & $1.06 \pm 0.15$ & - & - & - \\
\hline & (6) & (7) & & (4) & (5) & & & \\
\hline \multirow[t]{2}{*}{ A. muricata } & $0.38 \pm 0.36$ & - & - & - & - & - & - & - \\
\hline & (2) & & & & & & & \\
\hline \multirow[t]{2}{*}{ A. horrida } & - & 0.16 & - & 0.19 & 0.21 & - & - & - \\
\hline & & (1) & & (1) & (1) & & & \\
\hline \multirow[t]{2}{*}{ A. mossambica } & $0.55 \pm 0.49$ & 0.12 & - & - & - & - & - & - \\
\hline & (3) & (1) & & & & & & \\
\hline \multirow[t]{2}{*}{ A. tortuosa } & - & - & - & 0.24 & - & - & - & - \\
\hline & & & & (1) & & & & \\
\hline \multirow[t]{2}{*}{ A. aspera } & - & - & - & $0.43 \pm 0.21$ & $0.42 \pm 0.26$ & 0.11 & - & - \\
\hline & & & & (2) & (2) & (1) & & \\
\hline \multirow[t]{2}{*}{ A. nasuta } & $0.59 \pm 0.53$ & $0.51 \pm 0.18$ & - & - & - & - & - & - \\
\hline & (3) & (4) & & & & & & \\
\hline \multirow[t]{2}{*}{ A. sp. } & - & - & - & - & - & - & - & 0.19 \\
\hline & & & & & & & & (1) \\
\hline
\end{tabular}



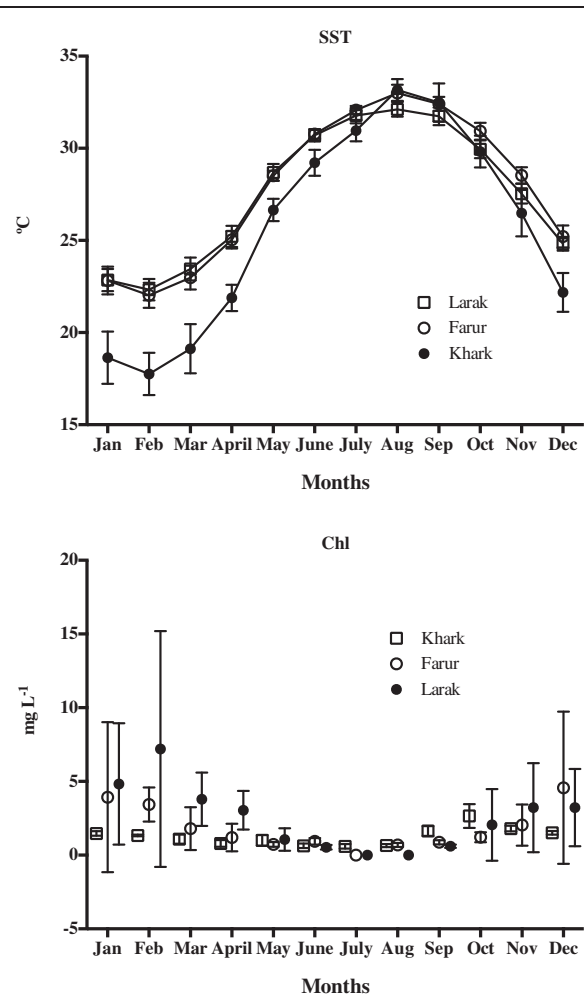
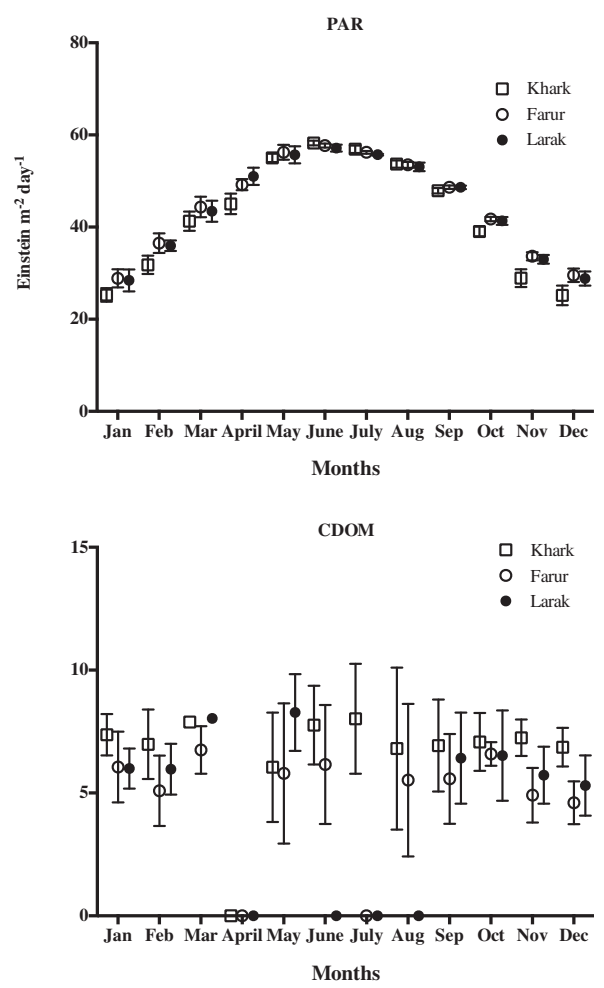

Figure 3 Monthly means of SST, PAR, Chl $a$, and CDOM between January 2007 and December 2011.

along the Iranian coast (Riegl et al. 2012) indicates the presence of 12 species in the gulf. Analyses from a previous study (Rahmani and Rahimian 2013) and from this study are probably the first intensive taxonomic and distributional surveys of Acropora along the Iranian coast.

Finding A. mossambica and A. tortuosa (Table 3) along the Iranian coast provides important implications for zoogeography of Acropora in the Persian Gulf. A. mossambica was originally described from southeastern Africa and later confirmed in reefs of the Western Indian Ocean (Riegl 1995; Wallace et al. 2012). Four colonies were found at Larak Island but not at Farur or Khark Islands, suggesting that this species is rare and limited to an area close to the Strait of Hormuz but is not found in the inner Persian Gulf. A. tortuosa was originally described from the central and western Pacific (Wallace 1999), and our finding of one colony at Farur Island is not only a new record for the Persian Gulf but also for the entire Indian Ocean. New records of Acropora species are expected to increase when more intensive surveys of other islands along the Iranian coast are conducted in the future.
Nevertheless, confusion over species identification occurred for other Acropora species in our study (see Rahmani and Rahimian 2013). We encountered difficulties in separating Acropora clathrata and A. downingi during field surveys, resulting in some confusion when subsequently grouping them for analytical purposes. The only differentiating character between these two species is that A. downingi often develops vertical branchlets, and its vertical and horizontal branches tend to be thinner in diameter and appear more fragile than those of neighboring $A$. clathrata colonies. In our study, colonies with only horizontal branchlets were difficult to differentiate from those with vertical and horizontal branchlets; therefore, we treated these two species as growth variations of $A$. downingi. An ongoing molecular phylogenetic examination of these two growth forms supports the belief that they belong to the same genetic lineage (data not shown). We hypothesize that reports of $A$. clathrata from the southern and western Persian Gulf (reviewed in Riegl et al. 2012) are either (1) misidentifications of $A$. downingi (Wallace 1999), (2) restriction of $A$. clathrata to the southern and western Persian Gulf, or (3) extreme

Table 4 LINKTREE analysis of Acropora

\begin{tabular}{lllllll}
\hline Node/station split & Variable & LHS (RHS) split & $\boldsymbol{\pi}$ & Significance $(\boldsymbol{p}$ value) & $\boldsymbol{R}$ & $\boldsymbol{B}(\%)$ \\
\hline $\mathrm{A}$ & Chl $a$ or CDOM & $<0.0165(>0.992)$ or $>-0.362(<-0.769)$ & 2.44 & 0.088 & 100 \\
\hline
\end{tabular}




\begin{tabular}{|c|c|c|}
\hline Number of variables & Best variable combinations & Correlation $\left(p_{w}\right)$ \\
\hline 1 & $\mathrm{Chl} a$ & 0.5 \\
\hline 1 & CDOM & 0.5 \\
\hline 2 & SST-Chl a & 0.5 \\
\hline 2 & SST-CDOM & 0.5 \\
\hline 2 & PAR-Chl a & 0.5 \\
\hline 2 & PAR-CDOM & 0.5 \\
\hline 2 & Chl a-CDOM & 0.5 \\
\hline 3 & SST-PAR-Chl a & 0.5 \\
\hline 3 & SST-Chl a-CDOM & 0.5 \\
\hline 3 & PAR-Chl a-CDOM & 0.5 \\
\hline
\end{tabular}

rarity of $A$. clathrata in the northern Persian Gulf. These hypotheses await further confirmation by molecular phylogenetic examination.

HSD tests revealed that although significant differences in Acropora diversity $\left(H^{\prime}\right)$ were observed between Larak and Khark Islands, Farur, which is located midway between those two islands, showed no significant difference with either Larak or Khark. This indicates a pattern of a gradual decrease in Acropora diversity from Larak towards the northern Persian Gulf. We think this trend could be due to (1) similar decreasing trends in ecological factors like Chl $a$ and CDOM along the gradient, (2) the Persian Gulf being a biogeographic 'island' distant from the 'mainland' of Iran, where species diversity gradually decreases with increasing distance, and (3) the Persian Gulf containing peripheral biological communities of the Indian Ocean, and in marginal communities, diversity usually decreases with increasing distance from the source because of the decreasing effects of environmental factors (Stehli and Wells 1971; Lomolino et al. 2010).

Biogeographically, there was a decreasing trend in Acropora diversity from the south to the north of the inner Persian Gulf and also differences in communities among these three islands. The Acropora community at Larak was dissimilar to those at Farur and Khark, whereas the latter two islands possessed similar community structures. Although only Acropora diversity and distributional patterns were examined in this study, our results were concordant with the general pattern of coral community differences reported by previous studies of the southern Persian Gulf, i.e., coral communities closer to the Strait of Hormuz are characterized by relatively high species diversity and richness and differ from those in the inner part of the Gulf (Sheppard 1987; Sheppard and Sheppard 1991; Riegl 1999; Bauman et al. 2013; reviewed in Sheppard et al. 1992; Riegl et al. 2012).
Richness, evenness, and the Shannon-Weaver index all exhibited low values for Acropora species at the three islands. Nevertheless, the TPC of Acropora, ranging from $38.52 \%$ in Larak to $24.01 \%$ in Khark, was relatively high compared to recently published data from the northeastern Arabian Peninsula, including the southeastern Persian Gulf, Strait of Hormuz, and Gulf of Oman. Acropora occupied $12.2 \%$ of the total benthic coverage in the Gulf of Oman, whereas it represented $<10 \%$ of the benthic coverage in the southeastern Persian Gulf and Strait of Hormuz (Bauman et al. 2013). At Qeshm Island, the largest Iranian island that is very close to Larak Island, no Acropora was found in surveys conducted in 2009 (Kavousi et al. 2011). It was proposed that recent disturbance, including cyclone Gonu in 2007 and a large-scale harmful algal bloom event in 2008, significantly impacted Acropora spp. in the Strait of Hormuz and Gulf of Oman (Maghsoudlou 2008; Bauman et al. 2010, 2013; Foster et al. 2012). Thus, high Acropora diversity and TPC suggest that these two disturbance events did not affect coral communities at Larak and Farur Islands, which are close to the Strait of Hormuz.

In our study, SSTs and PAR did not show significant differences among the three islands studied, while Chl $a$ and CDOM did. Coral communities vary across environmental gradients in the southern Persian Gulf, Strait of Hormuz, and Gulf of Oman, and are strongly correlated with considerable variations in oceanic conditions across the three regions, which exhibit strong directional environmental gradients (Bauman et al. 2013). Interestingly, although temperature and salinity were previously referred to as major environmental factors in structuring coral communities in the Persian Gulf (Sheppard and Sheppard 1991; Sheppard et al. 1992; Reynolds 1993; Coles 2003; Riegl et al. 2012), additional factors such as Chl $a$, surface currents, and winds were also identified as important parameters in structuring coral communities (Bauman et al. 2013). High Chl $a$ values in the Strait of Hormuz and Gulf of Oman are reportedly due to seasonal upwelling and monsoonal events (Reynolds 1993; Piontkovski et al. 2012; Riegl and Purkis 2012). The higher Chl $a$ at Larak Island might have been due to similar upwelling and monsoonal effects because of its location in the Strait of Hormuz. Data on complete coral diversity and environmental parameters are needed to clarify the impacts of environmental settings in structuring coral communities along the Iranian coast. Results of the BIO-ENV analysis also suggest a possible influence of Chl $a$ and CDOM on the coral communities at the three islands due to significant differences in CDOM values between Khark and Farur and Chl $a$ values between Larak and Khark.

Recent records of Acropora species (Rahmani and Rahimian 2013) and relatively high coverage values 
(from the present study) at islands off the Iranian coast provide important implications for coral reef resilience and mitigation procedures (e.g., assisted migration) in response to changing environmental conditions, not only for the Persian Gulf but also for the world's coral reefs under the impacts of climate change (Hoegh-Guldberg et al. 2008; Riegl et al. 2011). The Persian Gulf represents one of the most extreme examples of environmental conditions regarding the survival of corals and development of coral reefs (reviewed in Coles 2003; Riegl et al. 2012). At least three major bleaching events occurred in 1996, 1998, and 2002, and intensive human disturbances have locally driven Acropora spp. extinct in the southern and western Persian Gulf (reviewed in Sheppard et al. 2010; Riegl et al. 2012). Riegl et al. (2012) in their study proposed that Persian Gulf corals should be considered as candidates for assisted migration, to be introduced into the tropical Indo-Pacific where Acropora species have faced local extinctions due to mass coral bleaching events over the last decade. Utilizing the potential of Acropora from Iran would have the double benefit of avoiding local extinctions of the world's most heat-adapted corals and at the same time introducing their genetic information to populations new to such extremes, potentially assisting in their survival (Riegl et al. 2011). Acropora species found in this study could serve as sources for increasing the resilience of southern and western Persian Gulf reefs as well as reef-building corals targeted for assisted migration to Indo-Pacific reefs.

\section{Conclusions}

In conclusion, ten Acropora species at Larak Island from the Strait of Hormuz to Farur and Khark Islands in the inner Persian Gulf along the Iranian coast exhibited a distinct distributional pattern characterized by higher diversity at Larak Island off the Strait of Hormuz and lower diversity towards Farur and Khark Islands of the inner gulf. Chl $a$ and CDOM significantly differed between Larak Island and the other two islands, implying that these environmental factors could play important roles in structuring Acropora communities among these islands.

\section{Competing interests}

The authors declare that they have no competing interests.

\section{Authors' contributions \\ MRR, HR, and CAC designed and conceived the experiment. MRR and HR carried out all the survey and sampling. MRR, MA, SK, and SF performed the data analysis. CCW performed the identification of coral skeleton and taxonomy analysis. MRR, SK, CAC, and HR wrote the paper. All authors read and approved the final manuscript.}

\section{Acknowledgements}

The researchers express their gratitude to Hormozgan and Bushehr Environmental Protection Agencies and the Iran Offshore Oil Company for their valuable help and support during sampling. We wish to thank Dr. Fazel, Dr. Shirdam, Dr. Saeedpour, Dr. Montazami, Dr. Shokri, Capitan Mansur,
Capitan Sorori, Capitan Heidari, Mr. Namdar, Mr. Shokri, Mr. Moien, Mr. Tollab, Mr. Hadi, and Mr. Shirzad for their help and support during sampling procedures. SK was funded through an Academia Sinica postdoctoral fellowship (2013 to 2014). SF was a recipient of a Taiwan International Graduate Fellowship for doctoral studies. This study was financially supported by the Office of Research Affairs, University of Tehran.

\section{Author details}

${ }^{1}$ Faculty of Biology, College of Science, University of Tehran, Tehran 14155-6453, Iran. ${ }^{2}$ University of Environment, Standard Square, Karaj 31746-118, Iran. ${ }^{3}$ Environment and Sustainable Development Research Centre, Standard Square, Karaj 31746-118, Iran. ${ }^{4}$ Biodiversity Research Center, Academia Sinica, Nangang, Taipei 115, Taiwan. ${ }^{5}$ Taiwan International Graduate Program (TIGP)-Biodiversity, Academia Sinica, Nangang, Taipei 115, Taiwan. ${ }^{6}$ Museum of Tropical Queensland, Townsville, Queensland 4810, Australia. ${ }^{7}$ Institute of Oceanography, National Taiwan University, Taipei 106, Taiwan.

Received: 11 May 2012 Accepted: 13 January 2013

Published: 4 November 2013

\section{References}

Abdi H (2007) Bonferroni test. In: Salkind NJ (ed) Encyclopedia of measurement and statistics. SAGE Publications, Thousand Oaks, CA, pp 104-108, doi:10.4135/9781412952644.n60

Bauman AG, Burt JA, Feary DA, Marquis E, Usseglio P (2010) Tropical harmful algal blooms: an emerging threat to coral reef communities? Mar Pollut Bull 60:2117-2122

Bauman AG, Feary DA, Heron SF, Pratchett MS, Burt JA (2013) Multiple environmental factors influence the spatial distribution and structure of reef communities in the northeastern Arabian Peninsula. Mar Pollut Bull 72(2):302-312

Beenaerts N, Berghe EV (2005) Comparative study of three transect methods to assess coral cover, richness and diversity. West Indian Ocean J Mar Sci 4:29-37

Clarke KR, Warwick RM (2001) Change in marine communities: an approach to statistical analysis and interpretation. PRIMER-E, Plymouth

Coles SL (2003) Coral species diversity and environmental factors in the Arabian Gulf and the Gulf of Oman: a comparison to the Indo-Pacific region. Atoll Res Bull 507:1-19

Coles SL, Fadlallah YH (1991) Reef coral survival and mortality at low temperatures in the Arabian Gulf: new species-specific lower temperature limits. Coral Reefs 9:231-237

Fatemi SMR, Shokri MR (2001) Iranian coral reefs status with particular reference to Kish Island, Persian Gulf. International Coral Reef Initiative Indian Ocean Regional Workshop, Muzambique, pp 1-12

Foster NL, Paris CB, Kool JT, Baums IB, Stevens JR, Sanchez JA, Bastidas C, Agudelo C, Bush P, Day O, Ferrari R, Gonzalez P, Gore S, Guppy R, McCartney MA, McCoy C, Mendes J, Srinivasan A, Steiner S, Vermeij MJ, Weil E, Mumby PJ (2012) Connectivity of Caribbean coral populations: complementary insights from empirical and modelled gene flow. Mol Ecol 21:1143-1157

Hoegh-Guldberg O, Hughes L, Mclntyre S, Lindenmayer DB, Parmesan C, Possingham HP, Thomas CD (2008) Assisted colonization and rapid climate change. Science 321:345-346

Kavousi J, Seyfabadi J, Rezai H, Fenner D (2011) Coral reefs and communities of Qeshm Island, the Persian Gulf. Zool Stud 50:276-283

Lomolino MV, Riddle BR, Whittaker RJ, Brown JH (2010) Biogeography, 4th edn. Sinauer Associates, Sunderland

Maghsoudlou A (2008) Hard corals of the Iranian coastal waters of the Persian Gulf. Iranian National Institute for Oceanography, Tehran, in Persian

Piontkovski SA, Al-Gheilani HMH, Jupp BP, Al-Azri AR, Al-Hashmi KA (2012) Interannual changes in the sea of Oman ecosystem. Open Mar Biol J 6:38-52

Rahmani MR, Rahimian H (2013) Preliminary study on Acropora (Scleractinia: Astrocoeniina: Acroporidae) of the Persian Gulf, with emphasis on its north and northeastern parts. Turk J Zool 37:308-320

Reynolds RM (1993) Overview of physical oceanographic measurements taken during the Mt. Mitchell cruise to the ROPME sea area. Scientific workshop on results of the R/N Mt. Mitchell cruise in the ROPME sea area, vol. 1. Regional Organization for the Protection of the Marine Environment (ROPME), Safat, State of Kuwait 

of the world. Australian Institute of Marine Science, Townsville, Queensland, pp 155-170

Rezai H, Samimi-Namin K, Kabiri K, Jalili M, Ghavam Mostafavi P, Mokhtar M (2007) Distribution and abundance of corals around Hengam and Farurgan Islands, Persian Gulf. Iranian National Centre for Oceanography, Department of Living Sciences. Report no. 385-1-08, Tehran, in Persian with English abstract

Rezai H, Samimi-Namin K, Kabiri K, Kamrani E, Ghavassi M (2009) Coral degradation, distribution and abundance around Larak and Kish Islands, Persian Gulf. Iranian National Centre for Oceanography, Department of Living Sciences: report no. 386-1-09, Tehran, Iran, in Persian with English abstract

Riegl B (1995) Description of four new species in the hard coral genus Acropora Oken, 1815 (Scleractinia: Astrocoeniina: Acroporidae) from south-east Africa. Zool J Linn Soc Lond 113:229-247

Riegl B (1999) Corals in a non-reef setting in the southern Arabian Gulf (Dubai, UAE): fauna and community structure in response to recurring mass mortality. Coral Reefs 18:63-73

Riegl BM, Purkis SJ (2012) Dynamics of gulf coral communities: observations and models from the world's hottest coral sea. In: Riegl BM, Purkis SJ (eds) Coral reefs of the gulf: adaptation to climatic extremes: coral reefs of the world, volume 3. Springer, Dordrecht, doi:10.1007/978-94-007-3008-3_6

Riegl BM, Purkis SJ, Al-Cibahy AS, Abdel-Moati MA, Hoegh-Guldberg O (2011) Present limits to heat-adaptability in corals and population-level responses to climate extremes. PLoS One 6:e24802

Riegl BM, Purkis SJ, Al-Cibahy AS, Al-Harthi S, Grandcourt E, Al-Sulaiti K, Baldwin J, Abdel-Moati A (2012) Coral bleaching and mortality thresholds in the SE Gulf: highest in the world. In: Riegl BM, Purkis SJ (eds) Coral reefs of the gulf: adaptation to climatic extremes: coral reefs of the world, volume 3. Springer, Dordrecht, doi 10.1007/978-94-007-3008-3_6

Sheppard CRC (1987) Coral species of the Indian Ocean and adjacent seas: a synonymized compilation and some regional distributional patterns. Atoll Res Bull 307:1-32

Sheppard CRC, Sheppard ALS (1991) Corals and coral communities of Arabi. Fauna Saudi Arabia 12:1-170

Sheppard CRC, Price P, Roberts C (1992) Marine ecology of the Arabian region. Academic, London

Sheppard C, Al-Husiani M, Al-Jamali F, Al-Yamani F, Baldwin R, Bishop J, Benzoni F, Dutrieux E, Dulvy NK, Durvasula SR, Jones DA, Loughland R, Medio D, Nithyanandan M, Pilling GM, Polikarpov I, Price AR, Purkis S, Riegl B, Saburova M, Namin KS, Taylor O, Wilson S, Zainal K (2010) The Gulf: a young sea in decline. Mar Pollut Bull 60:13-38

Stehli FG, Wells JW (1971) Diversity and age patterns in hermatypic corals Syst Zool 20:115-126

Wallace CC (1999) Staghorn corals of the world: a revision of the coral genus Acropora (Scleractinia; Astrocoeniina; Acroporidae) worldwide, with emphasis on morphology, phylogeny and biogeography. CSIRO Publishing, Collingwood, Victoria

Wallace CC, Done BJ, Muir PR (2012) Revision and catalogue of worldwide staghorn corals Acropora and Isopora (Scleractinia: Acroporidae), 57th edn. Memoirs of the Queensland Museum, Brisbane, pp 1-255

doi:10.1186/1810-522X-52-40

Cite this article as: Rahmani et al: Acropora distribution patterns in the northern and northeastern Persian Gulf. Zoological Studies 2013 52:40.

\section{Submit your manuscript to a SpringerOpen ${ }^{\circ}$ journal and benefit from:}

- Convenient online submission

- Rigorous peer review

- Immediate publication on acceptance

- Open access: articles freely available online

- High visibility within the field

- Retaining the copyright to your article

Submit your next manuscript at $\gg$ springeropen.com 